DOMINIKA KACZOROWSKASPYCHALSKA

\title{
Consumer perspective of omnichannel commerce
}

Dominika Kaczorowska-Spychalska, Ph.D.

University of Lodz Faculty of Management Department of Marketing

\section{Introduction}

"The 20th century witnessed the onset of a new revolution. The advent of the Internet irreversibly changed a lot of areas of life. Thanks to that the world became smaller and within reach. [...] Competition among enterprises entered a new market space that is created by networks and at the same time, new players appeared. Commerce that used to be constrained by numerous barriers thanks to the Internet entered a new level and was defined in a new way."(Jasiński 2016, p.27). The advent of the online channel and new additional digital channels such as mobile channels and social media have changed retail business models, the execution of the retail mix and shopper behavior (Verhoef et al. 2015, pp. 174-181). The space of human - computer interaction causes that companies/brands have to look at the market, their strategy, undertaken activities and their offer through the consumer, their experience, emotions and recollections. So, online and offline sales should freely percolate and complement. A growing number of brands present in Poland start to understand a consumer's perspective that perceives a distribution network as one entity regardless of a place and channel of 
sales. As a result, solutions that are implemented blur the boundaries between them and complement one other (Czerpak, 2017, p. 10). Therefore, omnichannel model is a concept based on complementarity enabling to increase conversion as a result of synergy of sales conducted in a number of channels. Implementation of omnichannel strategy is not about user's convenience - it is a question of to be or not to be for a brand (Conversion, 2017, p.11). A prerequisite of such an approach is hedonic motivation of a consumer that will try to maximize experiences connected with a feeling of delectation at the same time rejecting some that are perceived and associated negatively. Experience is everything for him. Consumers are looking for experiences that enable them to realize their dreams and achieve their desired lifestyle (Smith, Wheeler 2002, p. 1). That is why providing a value that is essential and engaging in their opinion, in such an approach, requires a holistic approach from companies/brands that merges technology with areas of product management, logistics, marketing and processes observed within an organization.

The purpose of the paper is to present how the essence of omnichannel commerce is perceived by consumers with special regard to their preferences in that area. Part one presents - based on the relevant literature - the essence of omnichannelity in commerce. A particular focus was put on prerequisites of the development of that concept and its relevance for companies/brands. In further parts the author presents results of own studies regarding an issue of omnichannelity in consumers' opinions with special regard to prerequisites influencing a choice of a channel of sales, also in online sales, their preferences regarding a place of purchase, a method of placing an order, a form of payment or delivery.

\section{Consumer in the space of omnichannel commerce}

An increase in the level and range of using the Internet enables to create a wide spectrum of opportunities that can be generated in commerce and thus contribute to the evolution of a man-consumer and to maximize benefits from using current market trends. It is a kind of a catalyst of changes leading to a new state of affairs which is called the digital egalitarianism. It is expressed by creating equal opportunities and potentials in three dimensions that directly influence one another: business, consumer and social one (Ratnicyn 2016, p. 25). Pace and expressiveness of observed changed resulted in modification of retail market space that ceased to be hermetic. What is frequently observed is an increased synergy of online and offline channels, which has a strong 
impact on the growth of dynamics and directions of its development. Experts collectively predict that this sector will be continually growing in Poland and the pace will be double-digit. As the report of E-commerce Standard 2016 states up to $78 \%$ of Polish online shops achieved a growth of sales on an annual basis and for $45 \%$ it exceeded $20 \%$. Moreover, in some industries a mobile channel already surpassed orders from desktops (Watras 2017, pp. 30-33). At the same time conclusions from the report of the Polish Chamber of Digital Economy "M-commerce. Kupuje mobilnie 2016" indicate that various purchasing activities through mobile devices are conducted by $97 \%$ users. Among mobile consumers up to $39 \%$ buy regularly by means of a mobile device, however, in case of those making buying decision on a smartphone - it is already 76\% (Grzybowska 2016 , pp. 14-20). One of the factors intensifying this process is the omnichannel strategy.

The omnichannel concept is perceived as an evolution of multichannel retailing, which implies a division between the physical and online store. In the omnichannel environment, customers move freely among channels (online, mobile devices, and physical store), all within a single transaction process.Because the channels are managed together, the perceived interaction is not with the channel, but rather the brand (Juaneda-Ayensa et al. 2016, p. 2). As a result, by permeating individual channels of sales simultaneity is observed at every level of undertaken activities. Thanks to that a consumer does not notice any differences between them. They notice only a brand and related experiences. On the other hand, a brand has an opportunity to integrate and aggregate information concerning a given consumer, regardless of a chosen channel and how a purchase was made. Thus, a consumer and complexity of buying process become a key element of activities of companies/ brands undertaking actions in the area of the omnichannel commerce strategy. What must focus around it are: a perfect product, technology, a channel of distribution, loyalty programmes and marketing campaigns (Narożyńska 2015, pp.67-69).The strategy of omnichannel commerce aims to ensure a coherent, well-consolidated offer for a consumer on many grounds of sales, from traditional shops, through catalogues, mobile devices or social media. What is of crucial importance is the fact that regardless of the way how and where a consumer eventually makes a purchase, they want to get a product of the same price and quality, with all related benefits (Chodowicz 2015, pp.7072). As a result, a company/brand has a chance to build relations based on experiences that are complex, coherent and available in every used channel while providing a consumer with holistic experiences during each stage of 
a purchasing process, at each point of contact and micro-moments of that interaction. A consumer starts "a shopping journey" in social media, views information on websites, subscribes a newsletter, and finishes it in a traditional shop where at the very last moment before buying, already holding a product in their hands, they look through its reviews on a smartphone (so called CrossScreen). At every stage of that journey brand's communication is carefully adjusted to the context and to a product that is currently searched for (Miśta, 2017, pp. 19-24). From a marketing point of view it is a specific promise for a consumer. A promise to meet difficult requirements of clients that very quickly adapt to new technologies as well as those who promptly follow them (Murzyn, 2017, pp.11-14), making an attempt to build experiences with a brand from a number of perspectives (Niechajewicz 2015, pp.24-27). What is widely observed under the influence of technologies is a growth of awareness, abilities and requirements of a contemporary consumer as they evolved from homo sapiens toward a homo cybereconomicus model. A consumer became an active participant in a process of creating and shaping values evolving into to a trying consumer (tysumer) whose behaviour and buying decisions are conditioned by hedonism. Having an unlimited choice of brands and offers they make a selection, choosing such that generate, in their opinion, feelings associated with pleasure, often exceeding their expectations and rejecting those which are perceived pejoratively. That way they make a projection of their identity and lifestyle while manifesting their personality and supported values. For contemporary consumers these are not products but, first of all, related experiences that are a symbol of autonomy and status (BoguszewskaKreft 2013, p. 47).The bottom line is that not only experiences must be adjusted to real needs in every channel of sales independently, but, as it is the case in multichannel strategy, they must be consistent. A role of experiences with a company/brand is connected with offering buyers sensual, emotional, cognitive and relation values that complement the functional ones. However, a notion of a value that cannot be examined only in a utilitarian context, requires to be extended, and first of all, must be perceived in connection with a category of experiences (Skowronek 2012, p. 165). 'Value' doesn't mean "value for the money', but the satisfaction of multiple dimensions of value, from physical to emotional, from social to intellectual, from spiritual to occupational (Manu 2015, p. 9). Functionality does not only boil down to aspects related to product usefulness, but also to preferred channels of communication, forms of delivery, forms of payment, service in a traditional point of sale and in an online shop, which increase a sense of values and emotions experienced 
by a consumer. This is a definitely higher level than in case of traditional solutions, which results from a more complex and multilateral level of interaction as well as implementation of more advanced technologies as for example: Data Management Platform, Artificial Intelligence or the Internet of Things concept, especially in a cognitive approach. They increase a range of experiences that a consumer obtains and related intensity of emotions. Thus, for example, thanks to micro-localization technology it is possible to determine a place where a consumer is, identify time that they spent with a specific product and analyse their individual reactions and behaviors as well as to deliver purchased products to any place they are at a given moment of time, or to indicate availability of a specific product in given points of sale. When a consumer walks past a shop where there is some promotion, it is the ibeacon's role to inform them about it by sending a message to a smartphone. In the longer term, data collected about preferences and habits of a user can form their coherent profile, and what follows, will enable to anticipate their buying intentions (Grzybowska 2016, pp. 14-20) according to their Customer Lifetime Cycle.

Nowadays the commerce already uses so-called "bots" that imitate sellers and talk to potential consumers collecting both, behavioral and transactional information about them. There are also some mobile devices which allow customers to scan products in a traditional shop (e.g. Scan\&Shop) and some cash-point devices that allow to make payments with credit or debit cards in any place. Clothes market offers an attractive solution of smart fitting rooms. They enable to display on a screen installed in that room an item that a consumer has just returned with its other variants (size, colour). They also enable to prepare an individual composition by selecting accessories available at that moment in a shop. A similar role is played by virtual mirrors that are e.g. installed in some of Eva Minge\&Esotiq stores that enable to show the whole collection, thanks to which customers can quickly and easily find a fitting outfit. What is more, smart mirrors while analyzing our body can offer hints concerning styling, enable to take a picture in it and to place it on Facebook. Such actions make a purchasing process more attractive, thanks to which a consumer is interested and wants to participate while remaining in an interaction with a specific brand. It allows to extend shopping space and finalize a transaction of a high level of satisfaction in a relatively short time. For this reason, what every company needs to do, then, is create an experience, that first gains potential customers' attention, then gets them to spend time experiencing their offerings and finally causes them to spend their money by buying these offerings (Sundbo, Serensen 2013, p.30).Omnichannel 
commerce is a volatile and dynamic environment that is stimulated with interoperability of systems as well as parallelism and simultaneity of processes and activities (Gotwald-Feja 2016, p. 18). In spite of the fact that majority of Polish companies currently implement only selected elements such as e.g. an option of "Click\&Collect", it is definitely a very progressive direction (Chochołowski 2017, pp. 30-40), which can dominate the world of e-retailing in the future and become the third wave of e-commerce.

\section{Omnichannel commerce in the eyes of shoppers in the light of own studies}

The main objective of conducted surveys was to identify the significance of omnichannel commerce in preferences and buying behaviour of consumers.The most important issues included: determination of the essence of omnichannel commerce from a consumer's perspective, evaluation of the impact of various experiences of clients connected with a purchasing process as a factor affecting a purchase and identification of areas in which the concept of omnichannel commerce is of greatest importance for consumers.

The research was conducted in a form of surveys and together with available literature constituted a basis for exploration of issues concerning multichannelity. It is one of the elements of broader research conducted by the author and concerning the application of the concept of the Internet of Things and its applications in various activities of enterprises, with particular regard to the level of their acceptance by consumers. Consumer's shopping experience resulting from their contact with a company/brand at many points of interaction can imply either its acceptance or negation in consumers' opinions. Adopting such an approach as a starting point of conducted discussion, is strictly connected with observed concentration on a consumer, their needs and expectations as a fundamental imperative of functioning of market entities in that trade sector in order to avoid a loss of client and/or transaction. Surveys were conducted in the period between February - June 2017 among students of the University of Łódź and Social Academy of Sciences. Students were the only subject of the study as it is a group that, apart from managerial staff, is still one of the biggest group of Polish Internet users (20\%), which was indicated by the results of the strategic report by IAB Polska "Internet 2016/2017"(Ciemniewska 2017, pp. 12-15). The method used in the study was a questionnaire, which resulted mainly from the character of the sample (its big size, dispersion - various courses, modes of studies). The measurement instrument was a questionnaire that consisted of 21 questions, where 6 of them were demographic questions that in the process of 
analysis were independent variables. They concerned: gender, age, registered address, mode and subject of studies as well as average time respondents spend online every day. The study was of idiographic character and was based on an interpretative approach. In effect, obtained results are slightly limited and should mainly refer to an examined group of respondents and their local context, at the same time requiring further interpretations.

716 students took part in the survey, and 670 correctly filled questionnaires were qualified for further analysis. Women were a prevailing group as they accounted for almost $72 \%$ of the surveyed. Slightly over $90 \%$ were people at the age of up to 34 and people below 25 accounted for $67 \%$ of respondents. The participants had a registered address in big towns of Łódź agglomeration (of over 30 thousand residents) $-44 \%$ and its smaller towns (below 5 thousand residents) $-29.4 \%$. Slightly over $45 \%$ of respondents declared that on average they daily spend from one to three hours online and almost $39 \%$ spend more than three hours that way. $64 \%$ of the respondents studied in an extramural mode, a dominant group were students of the $1^{\text {st }}$ cycle studies $-76.4 \%$. They included mostly students of such courses as: Management (55.4\%), Administration (15.3\%), Marketing (12.2\%) and Logistics (11.7\%). The other courses of studies were: Entrepreneurship and Management, Public Management, Human Resources Management, Business Analytics - they together accounted for $5.4 \%$.

In the examined group almost $93 \%$ admitted that they buy in online shops. The analysis of the results conducted according to assumed features of respondents indicates that these features differentiate their decisions concerning shopping by means of this channel although observed differences in majority of these features were not markedly significant. It turned out that up to $93.3 \%$ of the surveyed did shopping in online shops, both, in an age group below 25 and between 25 to 34 . However, in the group of people above 34 the value decreased to $86.4 \%$ of respondents. What is worth noting is the fact that in that group the proportion of people who do not buy online was almost twice as high as in any of the other age groups. The most common cause for a lack of interest in shopping by means of this channel were previous negative experiences connected with this form of shopping and too complicated buying procedure in the opinion of consumers, which was reflected in their fears concerning forms of payment, delivery, lack of acceptable forms of product presentations in various devices, etc. Taking into considerations a place of registered address as an independent variable, the biggest interest in online shopping was noticed among people from towns of between 15 to 30 thousand inhabitants (95.1\%) and above 30 thousand (93.7\%). Interest in shopping in online shops was growing with every subsequent 
year of studies: $90.8 \%$ of respondents in a group of students of the first year of the $1^{\text {st }}$ cycle studies and $96.4 \%$ in a group of students of the second year of the $2^{\text {nd }}$ cycle studies. It can be assumed that it results from the fact that they are professionally active people that want that way increase their comfort and optimize a moment of purchase. The time respondents spend online every day also influenced their willingness to buy that way. The longer time, the bigger willingness (86.3\% in a group of those active online less than one hour a day and $97.7 \%$ among respondents that spend online more than three hours a day). Such variables as: gender, mode and course of studies proved to be insignificant.

The products that respondents bought online were primarily clothes (19.\%), books and CDs (13.4\%), shoes (12.7\%) and cosmetics (11.2\%). They also made reservations and bought tickets online for various kinds of events such as: concerts, theatre performances, matches, etc. The most common reasons why they bought online was an extensive product range within individual categories of products $(16.6 \%$ of the surveyed) and frequently, they mentioned a price of individual products that was lower than in traditional shops $(14 \%)$. What also mattered for respondents were factors directly connected with a process of placing an order itself, such as availability of online shops 24 hours a day (12.5\%), convenience of placing an order related to functionality of an e-shop (12.3\%) and a possibility of placing an order by means of various devices $(12.2 \%)$. The least important factor were additional discounts for buying online (7.1\%) and a short time of delivery $(9.6 \%)$.

$95.5 \%$ of respondents admitted that they look for information about a product online so that they could go to a traditional shop and buy it. At the same time, slightly above $71 \%$ of respondents get acquainted with an offer in a traditional shop, but make a purchase online. Online places that were most often mentioned by respondents were shops from Allegro (30.8\%) and shops of brands they trust $(26.2 \%)$. One in four respondents chose an online shop that had a positive opinion among other users and slightly above $17 \%$ chose shops recommended by friends. What is interesting, there were $68 \%$ of respondents who admitted that they do not give thought whether they buy online or in a traditional shop treating them as one common sales space of a given brand. Almost one in three, however, perceives both channels independently (multichannel), identifying them as separate, not related forms of sales. As a result, they distinguish experiences that are associated with each channel separately and towards which they show a particular attitude and preferences. At the same time, $2 \%$ of the surveyed did not have any opinion about it. It is possible that they currently do not realize such needs and/or it does not matter for them from the point of view of the 
whole shopping process, values that it generates and further interactions with a brand.

There are a lot of elements that in respondents' opinions have some influence on developing positive experience connected with buying online. First of all, respondents mentioned availability of products $(22 \%)$, easiness of placing an order by means of various devices they use (19.5\%) as well as availability of numerous options related to payment (18.5\%) and forms of delivery (15.6\%). However, it seems that a notion of "omnis" has a wider context for them and refers also to multiplicity of solutions that can combine in an optimal composition while increasing variety of experiences and achieved level of satisfaction.

While placing an order, every other respondent used a laptop, whereas up to $33 \%$ used their smartphones and $16.5 \%$ operated a tablet at this stage. However, up to $73 \%$ admitted that at this stage they very often make use of more than one device. But, it does not mean a high proportion of transactions conducted in the examined group by means of mobile devices (so-called last-click effect). Respondents declared that they usually use them at initial stages of a purchasing process. They definitely enable consumers to find a specific products, compare its prices in various outlets, read opinions and recommendations of other users or initiate interactions through a company/brand profile in social media.

In order to make a payment respondents used mostly such solutions as: online bank transfer, which was indicated by almost $30 \%$ of respondents, and instant transfers by means of such payment services as PayU, Przelewy24 (27\%). Meanwhile, however, slightly above $18 \%$ of the surveyed admitted that they pay cash on receiving ordered goods and one in ten respondents paid by a traditional bank transfer at a post office or a bank. A method that proved not very popular were solutions based on contactless technology in a smartphone (e.g. Master Card, My Wallet, Orange Cash) which were indicated by only 3.8\% of respondents.

Goods purchased in online shops were mostly delivered to respondents by means of courier companies and easyPack by InPost. But simultaneously, three quarters of respondents declared that they also use an option of personal collection in a point of sale choosing a type of service called "ClickECollect". These were mainly respondents below 25 living in towns of more than 30 thousand residents, who spend more than three hours online. So, it might be a result that on one hand, is connected with bigger availability of traditional shops of famous brands in big cities, but it can also be related to respondents' bigger knowledge about new technologies and their related digital skills. Brands that use such a solution and were often mentioned by respondents included: Empik, Orsay, C\&A, Kaazar, 
Decathlon and Wittchen. Solutions connected with using the concept of the Internet of Things in commerce were identified by respondents to a marginal extent. They mostly equated them with a possibility of scanning products bought in traditional shops, chat bots used in online shops and beacons. None of respondents had a chance to meet such solutions as: smart fitting rooms, smart mirrors or smart advertising displays, which based on recognized respondent's gender or age would adjust their message. Meanwhile, however, respondents are aware that their consumer activity is continuously monitored by brands that based on their analysis and databases can undertake activities that are initiating and/or intensifying their purchasing process, which was indicated by up to $97 \%$ of respondents.

Conducted studies are of informative nature. They do not explain all aspects concerning omnichannel commerce, but they created a perspective for further research and analysis in this area. The author's observations and conclusions constitute an inception for critical reception, reflection and further studies.

\section{Conclusion}

Advances in technology have blurred the lines between physical and virtual environments, giving rise to the rapid development of omnichannel businesses in which online and offline channels converge to deliver a seamless shopping (Choudhury,Karahanna, pp. 179-200).Consumers hold the power and define the new rules of retail. As a multitude of interaction options and technologies emerge, so grows consumer expectation for retailers to deliver a personalized and consistent shopper experience across all sales channels (Bardwell, 2013, p. 1).For this reason, omnichannel businesses represent an unprecedented opportunity for retailers to leverage synergies between both channels in synchronizing their interactions with consumers across multiple touch points (Brynjolfsson et al., 2013, pp. 23-29). Although omnichannel commerce based on new technologies, including those connected with the IoT, seems to be at its initial phase of development, it definitely creates a wide spectrum of possibilities of effective and efficient leading a consumer to a final point of transaction. „In the near future successful online shops will be able to skillfully adjust to customer expectations both, in terms of price, offer as well as customer service whereas further development of e-commerce sector is perceived in the area of artificial intelligence understood as self-developing algorithm. Bots supporting customer service, engines of recommendations recognizing users' intentions or behaviorally targeted advertisements - these are "thinking machines" that accompany business every day will become smarter 
and smarter"( Watras2017, pp. 30-33). However, the question how brands will use them to maximize consumer shopping experience remains open. Following them, creating and anticipating consumers' expectations concerning a product and convenient shopping becomes a "sine qua non" condition of building positive associations related to a brand. These companies/brands that decide to accompany their consumer and fight for their interest in a multichannel approach, must look through a prism of a buyer's preferences, especially in terms of functionality and value that they ultimately generate for them while adjusting to their individual Customer Journey.

\section{Summary}

\section{Consumer perspective of omnichannel commerce}

The evolution of hypermedia space and growing saturation of the market with mobile devices, an increasing role of Big Data, which allow for multidimensional analysis of data from offline and online markets, growing popularization of solutions of Market Intelligence supported by Cloud Computing technology as well as development of potential and opportunities of adapting the Artificial Intelligence (AI) and Internet of Things (IoT) in commerce cause that customers and their experience become a major point of activity of companies/brands. Shopping experience of a buyer is an effect of multiple and multidimensional contacts, often conducted simultaneously in many channels and in the real time. It forces an increasingly growing number of challenges that companies/brands are presented with if they want to optimize a space of customer journey and have to ensure continuity, coherence and complexity of experiences for their customers. Searching or creating these benefits that customers expect and their constant development becomes a prerequisite in this situation so that variety of positive experiences resulting in customer satisfaction and happiness could be guaranteed.

The paper is an attempt to verify the essence of omnichannel commerce from the consumer's perspective. The author discusses a problem of omnichannel model while taking into consideration some elements that can influence building and intensification of buyers' experiences and behavior in various channels of commerce. The discussion is supported with the results of own studies in that area. 
Keywords: omnichannel commerce, retail trade, customer, Internet of Things (IoT).

\section{Streszczenie}

\section{Omnichannel commerce z punktu widzenia konsumenta}

Ewolucja przestrzeni hipermedialnej i coraz większe nasycenie rynku urządzeniami mobilnymi, wzrost roli Big Data, pozwalających na wielowymiarową analizę danych z rynku offi online, rosnąca popularyzacja rozwiązań w zakresie Market Intelligence, wspomaganych technologią Cloud Computing, a także rozwój potencjału i możliwości adaptacji Artificial Intelligence (AI) and Internet of Things (IoT) w handlu, sprawiają, że klient i jego doświadczenia stają się centralnym punktem aktywności firm/marek. Shopping experience nabywcy jest efektem jego wielokrotnych i wielopłaszczyznowych kontaktów, często realizowanych jednocześnie $\mathrm{w}$ wielu kanałach i w czasie rzeczywistym. Wymusza to coraz większe wyzwania stawiane przed firmami/markami, które chcąc optymalizować przestrzeń customer journej muszą zapewnić swoim konsumentem ciągłość, spójność i kompleksowość doświadczeń. Warunkiem koniecznym staje się poszukiwanie i/lub kreowanie tych korzyści, których realnie konsument oczekuje oraz ich ciągły rozwój, tak by zagwarantować mu różnorodność pozytywnych doznań prowadzących do jego zadowolenia i satysfakcji.

W artykule podjęto próbę zweryfikowania istoty omnichannel commerce $\mathrm{z}$ perspektywy konsumenta. Omówiono $\mathrm{w}$ nim problematykę wielokanałowości, z uwzględnieniem tych elementów, które mogą mieć wpływ na budowanie i intensyfikację doświadczeń i zachowań nabywców w różnych kanałach handlu. Prowadzone rozważania zostały poparte wynikami badań własnych w omawianym zakresie.

\section{Slowa}

kluczowe: omnichannel commerce, handel detaliczny, konsument, Internet of Things (IoT).

JEL

Classification: M31 


\section{References}

1. Jasiński J. (2016), Cele, modele I strategie e-biznesu, [in:] Dutko M. (ed.), Biblia e-biznesu 2. Nowy Testament, One Press, Helion, Gliwice 2016, pp.27-134.

2. Verhoef p., Kannan P., Inman J. (2015), From Multi-Channel Retailing to Omni-Channel Retailing: Introduction to the Special Issue on Multi-Channel Retailing, "Journal of Retailing", Vol. 91, pp.174-181.

3. Czerpak E., (2017),Omnichannel po polsku. Jak zatrzymać klientów sklepów stacjonarnych $w$ dobie e-commerce. Report e-Commerce, Knight Frank, Warszawa.

4. Conversion (2017), Trendy e-commmerce 2017-Report, Conversion, Warszawa.

5. Smith S., Wheeler J. (2002), Managing the customer experience. Turning customers into advocates, Prentice Hall, London.

6. Ratnicyn K. (2016), Jak nowe technologie zmieniaja biznes, Wyd. Słowa i Myśli, Lublin.

7. Watras S. (2017), e-Commerce, [in:] Schmidt W., Raport strategiczny Internet 2016/2017,pp. 30-33.

8. Grzybowska K. (2016), Mobile pozytywnie wptywa na sprzedaż, nawet jeśli nie kończymy tam transakcji, [in:] Bonek T. (ed.), Raport Marketing mobilny, Warszawa 2016, pp. 14-20.

9. Juaneda-Ayensa E., Mosquera A., Murillo Y. (2016), Omnichannel Customer Behavior: Key Drivers of Technology Acceptance and Use and Their Effects on Purchase Intention, "Front Psychology"No. 7:1117, pp.1-11.

10. Narożyńska R. (2015), Jak wykorzystać beacony w komunikacji omnichannel?, "Marketer+", No. (3): 18, pp. 67-69.

11. Chodowicz M. (2015), Zarządzanie cenami oraz dziataniami promocyjnymi z punktu widzenia spójności międzykanałowej strategii sprzedaży, "Marketer +", No. (3): 18, pp. 70-71.

12. Miśta G. (2017), Omnichannel sprowadza się do customer experience i osobistej więzi z klientem, [in:] Bonek T. (ed.), Raport e-commerce, Interaktywnie.com, Warszawa,pp. 19-24.

13. Murzyn K. (2017), Strategia omnichannel czego jeszcze o niej nie wiesz?,[in:] Czeremańska K.(ed.), Digital trends w e-commerce Imagine, Warszawa, pp. 11-14.

14. Niechajewicz M., (2015), Jak nie dać się pożreć konkurencji, "Marketer+", No (3): 18, pp.24-27.

15. Boguszewska - Kreft M. (2013),Marketing doświadczeń, Wyd. CeDeWu.pl, Warszawa.

16. Skowronek I. (2012), Marketing doświadczeń. Od doświadczeń klienta do wizerunku firmy, Wyd. Poltext, Warszawa.

17. Manu A. (2015), Value Creation and the Internet of Things, Gower publishing Limited, England. 
18. Grzybowska K. (2016),Mobile pozytywnie wptywa na sprzedaż, nawet jeśli nie kończymy tam transakcji, [in:] Bonek T. (ed.),Raport - Marketing mobilny, Warszawa, pp. 14-20.

19. Sundbo J., Serensen F.(2013),Handbook on the experience economy, Edward Elgar Publishing Limited, UK.

20. Gotwald-Feja B. (2016), Konsument w realiach omnichannel, SIZ, Łódź.

21. Chochołowski B.(2017), Omnichannel jestjakjednorożec.Ciagle onim styszymy, ale czy istnieje?,[in:] Bonek T. (ed.), Raport e-commerce, Interaktywnie.com, Warszawa, pp. 30-40.

22. Ciemniewska J. (2017), Użytkownicy Internetu w Polsce, [in:] Kolenda P. (ed.), Raport strategiczny - Internet 2016/2017, Warszawa 2017, pp.12-15.

23. Choudhury, V., Karahanna, E (2008), The Relative Advantage of Electronic Channels:A Multidimensional View, "MIS Quarterly", No. 32, pp. 179-200.

24. Bardwell Ch. (2013), Redefining the Shopper Experience With Omnichannel Retailing, IDC Retail Insight.

25. Brynjolfsson, E., Hu Y. J. and Rahman, M. S., (2013), Competing in the Age of Omnichannel Retailing, "MIT Sloan Management Review", No. 54, pp. 23-29.

26. Watras S. (2017), e-Commerce, [in:] Schmidt W., Raport strategiczny Internet 2016/2017, pp. 30-33. 